\title{
Relationship of multiple myeloma with ABO blood groups
}

\section{Multipl miyelomun $A B O$ kan grupları ile ilişkisi}

\author{
Didar Yanardağ Açık ${ }^{1}$ Mehmet Bankir ${ }^{2}$ Begüm Seyda Avci ${ }^{2}$ (D) \\ ${ }^{1}$ Department of Internal Medicine and Haematology, Adana City Education and Research Hospital, \\ Adana, Turkey \\ ${ }^{2}$ Department of Internal Medicine, Adana City Education and Research Hospital, Adana, Turkey
}

\begin{abstract}
Aim: Multiple myeloma is a heterogeneous, incurable haematological cancer that occurs as a result of the clonal proliferation of plasma cells. The impact of blood groups on human diseases and/or their role in the prognosis of the disease has attracted the attention of scientists since the discovery of blood groups. We investigated the blood group distribution of multiple myeloma patients and whether their blood groups are related to immunoglobulin type.

Materials and Methods: 75 multiple myeloma patients and 73128 control group were included in the study, which was planned retrospectively. The statistical evaluation was performed by using Statistical Package for Social Sciences (SPSS) software for Windows 20 (IBM SPSS Inc., Chicago, IL). The normal distribution of the data was evaluated with the Kolmogorov-Smirnov test.

Results: In multiple myeloma patients, the rate of $A$ and $B$ blood groups was low, and the rate of $O$ and $A B$ blood groups was high. Heavy chain $\lg A$ ratio was higher in $B$ blood group compared to other blood groups. On the other hand, IgG ratio was found higher in $\mathrm{O}$ blood group compared to other blood groups.

Conclusion: A relationship has been found between immunoglobulin type and blood types in multiple myeloma. More comprehensive studies are needed on this subject.
\end{abstract}

Keywords: Multiple myeloma; ABO blood group; monoclonal gammopathy.

\section{ÖZ}

Amaç: Multipl myelom plazma hücrelerinin klonal proliferasyonu sonucu oluşan, heterojen, kür sağlanamayan hematolojik bir kanserdir. Kan gruplarının insan hastalıklarına katkısı ve/veya hastalık seyrindeki rolü kan gruplarının keşfinden bu yana bilim insanlarının ilgisini çekmiştir. Multipl myelom hastalarının kan grubu dağılımını ve kan gruplarının immunglobulin tipi ile ilişkisinin olup olmadığını araştırdık.

Gereç ve Yöntem: Retrospektif planlanan çalışmaya 75 multipl myelom hastası ve 73128 kontrol grubu dahil edildi. Istatistiksel değerlendirme Statistical Package for Social Sciences (SPSS) for Windows 20 (IBM SPSS Inc., Chicago, IL) programı kullanılarak yapıldı. Verilerin normal dağılımı Kolmogorov-Smirnov testi ile değerlendirildi.

Bulgular: Multipl myelom hastalarında $A$ ve $B$ kan grupları oranı düşük, $O$ ve $A B$ kan grupları oranı yüksek saptandı. B kan grubunda ağır zincir IgA oranı diğer kan gruplarına kıyasla daha yüksek saptandı. IgG oranı ise O kan grubunda diğer kan gruplarına kıyasla daha yüksek saptandı.

Sonuç: Multipl myelomda immunoglobulin tipi ile kan grupları arasında bir ilişki bulunmuştur. Bu konuda yapılacak daha kapsamlı çalışmalara ihtiyaç vardır.

Anahtar Sözcükler: Multipl myelom, ABO kan grubu, monoklonal gammopati.

Corresponding author: Didar Yanardağ Açık

Department of Internal Medicine and Haematology, Adana

City Education and Research Hospital, Adana, Turkey

E-mail: didaryanardag@gmail.com

Application date: 08.02.2021

Accepted: 08.07.2021 


\section{INTRODUCTION}

Multiple myeloma (MM) is a heterogeneous, incurable haematological cancer that occurs as a result of the clonal proliferation of plasma cells (1). Various risk factors such as old age, male sex, positive family history, black race, and genetic factors increase the incidence of MM (2, 3).

Blood group antigens are found on the surface of many cells and tissues as well as erythrocytes. The impact of blood groups on human diseases and/or their role in the prognosis of the disease has attracted the attention of scientists since the discovery of blood groups. Contributions of ABO blood group system to human life have been investigated, in addition to the role of the $A B O$ system in cardiovascular, infectious, and neoplastic diseases (4-9).

The connections of molecules such as sICAM, $p$ selectin, IL-6, which have been shown to have roles in cancer metastasis and/or development, with blood groups have been confirmed in many studies (10-12). There have also been studies showing that the correlation between MM and these molecules $(13,14)$. Based on this mechanism, we investigated the blood group distribution of MM patients and whether their blood groups are related to the type of MM.

\section{MATERIALS and METHODS}

75 multiple myeloma patients diagnosed with MM according to the International Myeloma Working Group (IMWG) diagnostic criteria (15) and control group with 73128 individuals were included in the study. The study was conducted as a singlecentre and retrospective study with the approval of the ethics committee.

75 patients who were followed up in our clinic between September 2013 and December 2020 were retrospectively scanned using electronic database. Age, gender, blood type, type of multiple myeloma, heavy chain type, light chain type, presence of lytic lesions and laboratory findings, follow-up times, and prognosis of patients were recorded. The control group consisted of 73128 patients who did not have any malignant disease and who came to our hospital for any reason between 2018-2019. The blood groups of all patients were collected from the electronic database and the distribution of their blood group was determined.
We investigated the relationship between blood groups and MM by comparing the blood groups of the patients and the control group. We also examined whether blood groups in multiple myeloma patients are associated with the type of monoclonal immunoglobulin.

\section{Statistical Analysis}

The statistical evaluation was performed by using Statistical Package for Social Sciences (SPSS) software for Windows 20 (IBM SPSS Inc., Chicago, IL). The normal distribution of the data was evaluated with the Kolmogorov-Smirnov test. Numerical variables with normal distribution were presented as mean \pm standard deviation, while numerical variables that were not normally distributed were presented as median (minimum, maximum). Categorical variables are expressed as counts and percentages. Chi-square and Fisher's Exact Chi-Square test was performed to compare categorical data. ANOVA test was used for comparing normally distributed numerical variables among $\mathrm{ABO}$ groups. Kruskal Wallis $\mathrm{H}$ test was used to compare numerical variables that were not normally distributed. Cox regression analysis was used to evaluate risk factors associated with prognosis. Survival analysis according to blood groups was determined by Kaplan-Meier analysis.

\section{RESULTS}

The study population comprised 22 women $(31.9 \%)$ and 47 men $(68.1 \%)$, a total of 69 patients aged between 37-82 years (mean:64.0 \pm 10.9 years). Rates of blood types were determined as A blood type 34.8\% (n: 24), B blood type $15.9 \%$ (n: 11 ), O blood type $40.6 \%$ and $A B$ blood type $8.7 \%$ ( $n: 6)$. The distribution of blood groups of multiple myeloma patients compared to the blood groups of the control group is shown in (Table-1). As stated in the Table 1, the rate of $A$ and $B$ blood group is low in MM patients $(34.8 \%$ and $40.0 \% ; 15.9 \%$ and $18.4 \% ; p=0.005)$. The proportion of $O$ and $A B$ blood groups is high $(40.6 \%$ and $34.8 \% ; 8.7 \%$ and $6.8 \% ; \mathrm{p}=0.005$ ) in patients with $\mathrm{MM}$.

The distribution of demographic characteristics according to blood groups was not significantly different (Table-2). IgA heavy chain ratio was higher in $B$ blood group compared to other blood groups (A: $37.5 \%$, B: $54.5 \%$, 0: $21.4 \%, A B: 0 \%$; $\mathrm{p}=0.014)$. Ig $\mathrm{G}$ ratio was higher in $\mathrm{O}$ blood group than other blood groups (A: $58.3 \%$, B:36.4\%, 
$0: 60.7 \%$ and $A B: 33.3 \% ; p=0.014)$. Other clinical findings were not significantly different compared to blood groups (Table-2).
Between 2 and 103 months of follow-up, 29\% of the patients died. Blood groups, demographic findings, and clinical findings did not correlate with mortality (Table-3).

Table-1. Distribution of blood groups of multiple myeloma patients.

\begin{tabular}{cccc}
\hline ABO & $\mathbf{M M}$ & $\begin{array}{c}\text { Control } \\
\mathbf{n = 7 3 1 2 8}\end{array}$ & $\mathbf{p}$ \\
\hline group & $\mathbf{n = 6 9}$ & $29210(40.0)$ & \\
A & $24(34.8)$ & $13439(18.4)$ & $0.005^{\star}$ \\
B & $11(15.9)$ & $25540(34.8)$ & \\
AB & $28(40.6)$ & $4939(6.8)$ & \\
\hline
\end{tabular}

Categorical variables were presented as number (\%).

${ }^{*} p<0.05$ shows statistical significance.

Table-2. Distribution of demographic and clinical findings according to blood groups.

\begin{tabular}{|c|c|c|c|c|c|c|}
\hline Clinical findings & $\begin{array}{l}\text { Total } \\
\mathrm{n}=68\end{array}$ & $\begin{array}{c}A \\
n=24\end{array}$ & $\begin{array}{c}B \\
n=11\end{array}$ & $\begin{array}{c}0 \\
n=28\end{array}$ & $\begin{array}{c}A B \\
n=6\end{array}$ & p \\
\hline \multicolumn{7}{|l|}{ Gender } \\
\hline Female & $22(31.9)$ & $8(33.3)$ & $3(27.3)$ & $9(32.1)$ & $2(33.3)$ & \multirow{2}{*}{0.0999} \\
\hline Male & $47(68.1)$ & $16(66.7)$ & $8(72.7)$ & 19(67.9) & $4(66.7)$ & \\
\hline Age, years & $63.0 \pm 11.0$ & $60.7 \pm 12.0$ & $62.5 \pm 9.8$ & $63.0 \pm 10.7$ & $71.3 \pm 7.2$ & 0.207 \\
\hline \multicolumn{7}{|l|}{$\mathrm{Rh}, \mathrm{n}(\%)$} \\
\hline Positive & $62(89.9)$ & $23(95.8)$ & $10(90.9)$ & 25(89.3) & $4(66.7)$ & \multirow{2}{*}{0.190} \\
\hline Negative & $7(10.1)$ & $1(4.2)$ & $1(9.1)$ & $3(10.7)$ & 2(33.3) & \\
\hline \multicolumn{7}{|l|}{ Diagnosis, n (\%) } \\
\hline $\mathrm{MM}$ & $56(81.2)$ & $20(83.3)$ & $9(81.8)$ & $22(78.6)$ & $5(83.3)$ & \multirow{2}{*}{0.964} \\
\hline MM+ Plasmacytoma & $13(18.8)$ & $4(16.7)$ & $2(18.2)$ & $6(21.4)$ & $1(16.7)$ & \\
\hline \multicolumn{7}{|l|}{ Heavy chain type, n (\%) } \\
\hline $\lg A$ & $21(30.4)$ & $9(37.5)$ & $6(54.5)$ & $6(21.4)$ & - & \multirow{3}{*}{$0.014^{*}$} \\
\hline $\lg G$ & $37(53.6)$ & $14(58.3)$ & $4(36.4)$ & $17(60.7)$ & $2(33.3)$ & \\
\hline Non-secretory & $11(15.9)$ & $1(4.2)$ & $1(9.1)$ & $5(17.9)$ & $4(66.7)$ & \\
\hline \multicolumn{7}{|l|}{ Light chain type, n (\%) } \\
\hline Kappa & $48(69.6)$ & $15(62.5)$ & $9(81.8)$ & 18(64.3) & $6(100.0)$ & \multirow{3}{*}{0.286} \\
\hline Lambda & $18(26.1)$ & $9(37.5)$ & $2(18.2)$ & $7(25.0)$ & - & \\
\hline Non-secretory & $3(4.3)$ & - & - & $3(10.7)$ & - & \\
\hline \multicolumn{7}{|l|}{ Lytic lesion, n (\%) } \\
\hline No & $12(17.4)$ & $5(20.8)$ & $1(9.1)$ & $4(14.3)$ & $2(33.3)$ & \multirow{2}{*}{0.554} \\
\hline Yes & $57(82.6)$ & 19(79.2) & $10(90.9)$ & $24(85.7)$ & $4(66.7)$ & \\
\hline \multicolumn{7}{|l|}{ Prognosis, n (\%) } \\
\hline Survived & $49(71.0)$ & $17(70.8)$ & $8(72.7)$ & 19(67.9) & $5(83.3)$ & \multirow{2}{*}{0.977} \\
\hline Died & $20(29.0)$ & $7(29.2)$ & $3(27.3)$ & $9(32.1)$ & $1(16.7)$ & \\
\hline Follow-up time (months) & $17(2-103)$ & $16(3-97)$ & $14(4-103)$ & $17(2-48)$ & $36(11-48)$ & 0.142 \\
\hline
\end{tabular}

Numerical variables with normal distribution were shown as mean \pm standard deviation, whereas numeric variables that were not normally distributed were shown as median (minimum, maximum).

Categorical variables were presented as number (\%).

* $p<0.05$ shows statistical significance. 
Table-3. Relationship between demographic and clinical findings and mortality.

\begin{tabular}{|c|c|c|c|c|}
\hline \multirow[b]{2}{*}{ Clinical findings } & \multicolumn{2}{|c|}{ Survival } & \multicolumn{2}{|c|}{ Univariable Cox regresyon } \\
\hline & $\begin{array}{c}\text { Survived } \\
n=49\end{array}$ & $\begin{array}{c}\text { Died } \\
n=20\end{array}$ & HR (\%95 GA) & $\mathbf{p}$ \\
\hline \multicolumn{5}{|l|}{ Gender } \\
\hline Female & $18(36.7)$ & $4(20.0)$ & ref & \\
\hline Male & $31(63.3)$ & $16(80.0)$ & $3.21(0.93-11.08)$ & 0.064 \\
\hline Age, years & $61.3 \pm 11.1$ & $66.6 \pm 9.6$ & $1.03(0.98-1.08)$ & 0.271 \\
\hline \multicolumn{5}{|l|}{ ABO group, $n(\%)$} \\
\hline A & $17(34.7)$ & $7(35.0)$ & ref & \\
\hline$B$ & $8(16.3)$ & $3(15.0)$ & $0.48(0.10-2.38)$ & 0.373 \\
\hline 0 & $19(38.8)$ & $9(45.0)$ & $1.35(0.50-3.68)$ & 0.558 \\
\hline $\mathrm{AB}$ & $5(10.2)$ & $1(5.0)$ & $0.30(0.04-2.45)$ & 0.258 \\
\hline \multicolumn{5}{|l|}{$\mathrm{Rh}, \mathrm{n}(\%)$} \\
\hline Positive & $43(87.8)$ & $19(95.0)$ & ref & \\
\hline Negative & $6(12.2)$ & $1(5.0)$ & $0.64(0.08-4.89)$ & 0.669 \\
\hline \multicolumn{5}{|l|}{ Diagnosis, n (\%) } \\
\hline MM & $37(75.5)$ & $19(95.0)$ & ref & \\
\hline MM+ Plasmacytoma & $12(24.5)$ & $1(5.0)$ & $0.26(0.04-1.97)$ & 0.193 \\
\hline \multicolumn{5}{|l|}{ Heavy chain, $n(\%)$} \\
\hline $\lg A$ & $15(30.6)$ & $6(30.0)$ & ref & \\
\hline $\lg G$ & $25(51.0)$ & $12(60.0)$ & $0.71(0.26-1.95)$ & 0.508 \\
\hline Non-secretory & $9(18.4)$ & $2(10.0)$ & $0.32(0.06-1.64)$ & 0.171 \\
\hline \multicolumn{5}{|l|}{ Light chain n (\%) } \\
\hline Kappa & $34(69.4)$ & $14(70.0)$ & ref & \\
\hline Lambda & $13(26.5)$ & $5(25.0)$ & $1.28(0.44-3.70)$ & 0.65 \\
\hline Non-secretory & $2(4.1)$ & $1(5.0)$ & $0.87(0.11-6.78)$ & 0.9 \\
\hline \multicolumn{5}{|l|}{ Lytic lesion, n (\%) } \\
\hline No & $8(16,3)$ & $4(20.0)$ & ref & \\
\hline Yes & $41(83.7)$ & $16(80.0)$ & $0.76(0.25-2.28)$ & 0.618 \\
\hline Follow-up time (months) & $18(2-97)$ & $15(3-103)$ & - & \\
\hline
\end{tabular}

Numerical variables with normal distribution were shown as mean \pm standard deviation, whereas numeric variables that were not normally distributed were shown as median (minimum, maximum).

Categorical variables were presented as number (\%).

* $p<0.05$ shows statistical significance.

Abbreviations: ref: reference, HR: hazard ratio, $\mathrm{Cl}$ : confidence interval

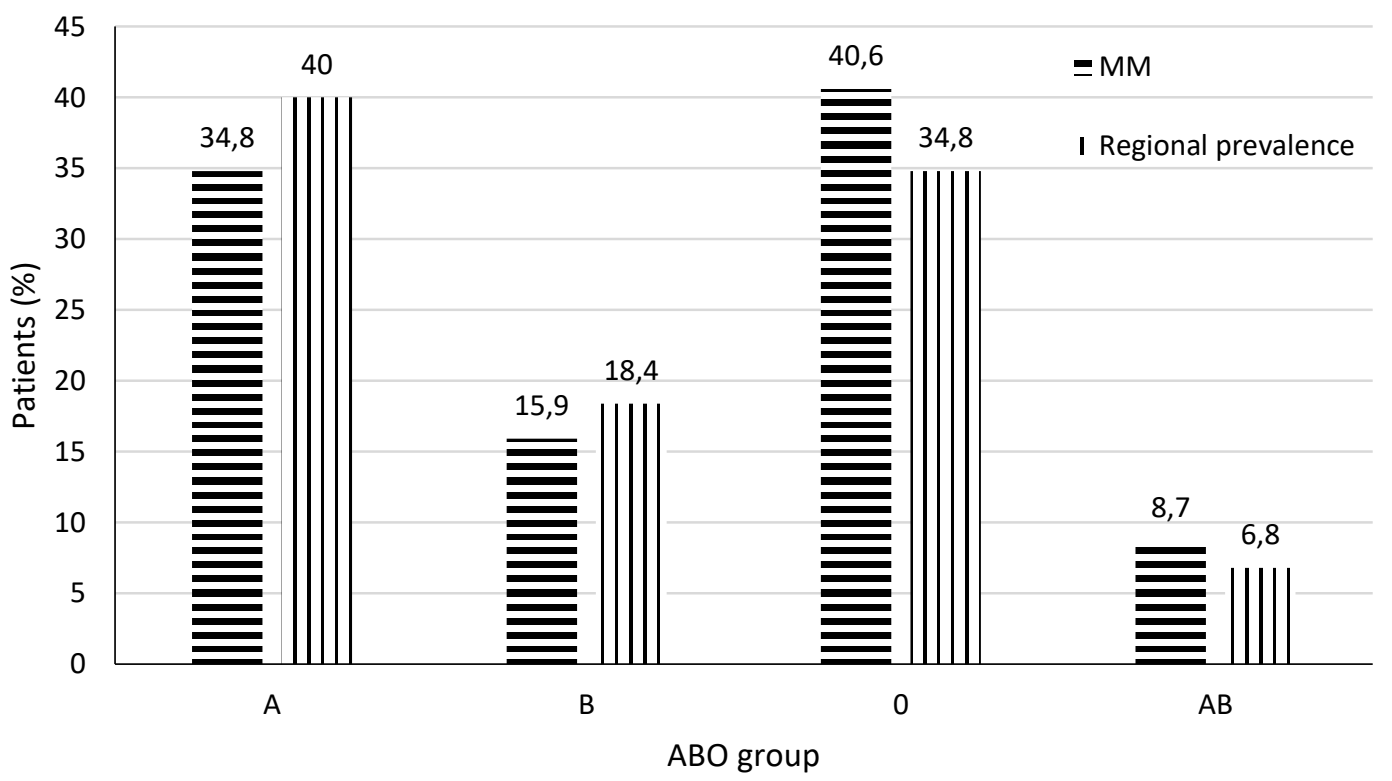

Figure-1. Distribution of blood groups. 

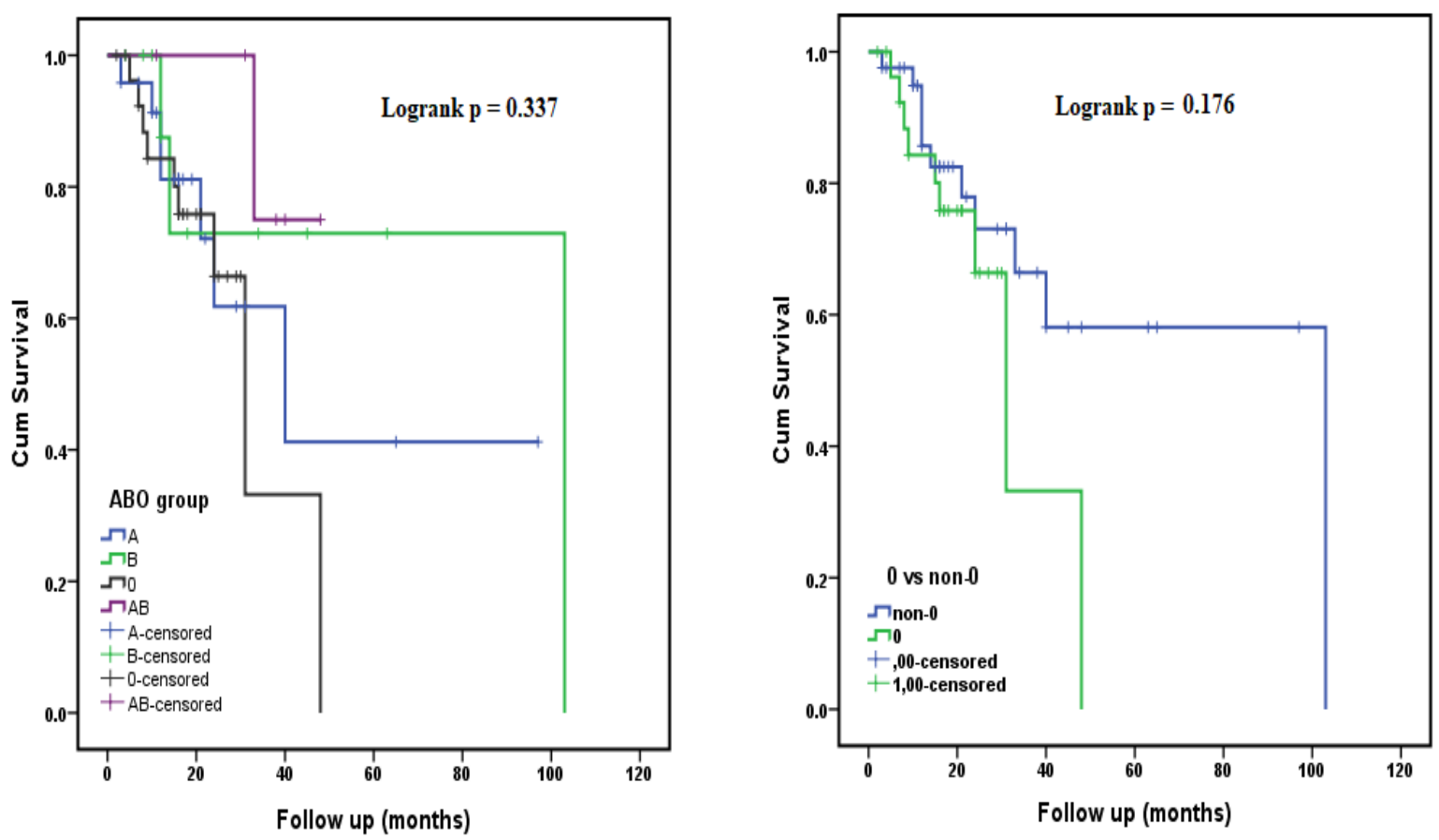

Figure-2. Overall survival curves of multiple myeloma patients according to blood groups AB0 group (A), and 0 versus non-0 group (B).

\section{DISCUSSION}

Environmental factors play an important role in the development of many types of cancer and other diseases $(16,17)$. Similarly, environmental factors determine the distribution of blood groups in that region $(18,19)$. Thereby, the results of studies investigating the relationship between diseases and blood groups are mostly inconsistent. Only two cancer studies have yielded consistent results among the studies on cancer and blood groups. The relation of the stomach and pancreatic cancer with blood groups is almost certain $(20,21)$.

Results are also contradictory in haematological cancer researches. Tavasolian F. et al. showed in their study that patients with $A B$ blood group had a higher rate of acute lymphoblastic leukemia (ALL) (22). In one study, an increase in the rate of $\mathrm{O}$ blood group was demonstrated among female patients with acute leukemia (23). In contrast, Jackson et al. reported a decrease in the rate of $\mathrm{O}$ blood group among female patients with acute leukemia (24). In another study, they could not find a difference in the distribution of $\mathrm{ABO}$ blood group among patients with acute leukemia compared to the general population (25). In a recent study investigating the relationship between multiple myeloma and blood groups, they found that the frequency of $\mathrm{O}$ blood group in MM patients was significantly lower than in the normal population. In the same study, they determined that the $\mathrm{O}$ blood group was a predisposing factor for the development of extramedullary lesions and also showed that the O blood group was associated with more aggressive disease (26). In contrast to the previous study, the rate of $A$ and $B$ blood groups was low, and the rate of $O$ and $A B$ blood groups was high in $M M$ patients in our study. A remarkable relationship was found between blood groups and immunoglobulin class. The proportion of IgA type multiple myeloma was found higher in B blood group compared to other blood groups, and $\operatorname{lgG}$ ratio was higher in $O$ blood group compared to other blood groups. There was no relationship between blood types and life expectancy. With the fact that it is not known which mechanism plays a role in the relationship between blood groups and immunoglobulin class, it can be hypothesized that infectious agents and/or chemical agents play a role in this mechanism. The correlation between infectious agents and blood groups has been shown in many studies $(27,28,29)$. IgA is involved in mucosal defence while IgG provides a long-lasting defence against infectious agents. Their chronic stimulation can lead to the clonal 
evolution of plasma cells. Multiple myeloma is more common in farmer population. Farmers are chronically exposed to infectious agents, animals, and pesticides more than people in industrialized areas (30).

In haematological malignancies, the red blood cell antigen may undergo variation. The most common cause of $A B O$ antigen variation is acute myelogenous leukemia $(31,32)$. There are two possible mechanisms for the weakening of $A B O$ antigens in hematopoietic diseases. The first mechanism is the inactivation of $A / B$ transferases and the second is the inactivation of $\mathrm{H}$ transferase (33-36). Loss of $\mathrm{ABO}$ antigens have also been demonstrated in multiple myeloma cases (32).

The relationship between integrins and von Willebrand factor (vWF) levels, which have been shown to play a role in cancer pathogenesis, with blood groups have been demonstrated in several studies $(10,37-40)$. Studies have shown that both vWF and intercellular adhesion factors play a role in multiple myeloma $(41,42)$.

We can associate the relationship between multiple myeloma and blood groups with infections, chromosomal abnormalities, integrins, and coagulation factors. However, the underlying mechanism is not yet clear, and extensive researches are needed on this topic.

\section{Limitations}

The limitations of our study are the small number of patients and short follow-up periods. Follow-up periods of the patients are not sufficient to indicate the effects of $\mathrm{ABO}$ blood group on $\mathrm{MM}$ prognosis.

\section{Conflict of interest}

There is no conflict of interest between the authors.

\section{References}

1. Brigle K, Rogers B. Pathobiology and diagnosis of multiple myeloma. Semin Oncol Nurs. $2017 ; 33$ (3): $225-236$.

2. Alexander DD, Mink PJ, Adami HO, et al. Multiple myeloma: a review of the epidemiologic literature. Int $\mathrm{J}$ Cancer. 2007; 120 (S12): 40-61.

3. Razi B, Anani Sarab G, Omidkhoda A, Alizadeh S. Multidrug resistance 1 (MDR1/ABCB1) gene polymorphism (rs1045642 C> T) and susceptibility to multiple myeloma: a systematic review and metaanalysis. Hematology. 2018; 2: 1-7. doi: 10.1080/10245332.2018.1443897.

4. Anstee DJ. The relationship between blood groups and disease. Blood 2010; 115: 4635-43.

5. Franchini M, Favaloro EJ, Targher G, Lippi G. ABO blood group, hypercoagulability, and cardiovascular and cancer risk. Crit Rev Clin Lab Sci 2012; 49: 137-49.

6. Vadivelu MK, Damodaran S, Solomon J, Rajaseharan A. Distribution of ABO blood groups in acute leukaemias and lymphomas. Ann Hematol. 2004 Sep; 83 (9): 584-7. doi: 10.1007/s00277-004-0888-1.

7. Cserti-Gazdewich CM, Mayr WR, Dzik WH. Plasmodium falciparum malaria and the immunogenetics of $A B O$, HLA, and CD36 (platelet glycoprotein IV). Vox Sang 2011; 100: 99-111.

8. Shimizu K, Hirose N, Ebihara Y, et al. Blood type B might imply longevity. Exp Gerontol 2004; 39: $1563-5$.

9. Sturgeon P, Beller S, Bates E. Study of blood group factors in longevity. J Gerontol 1969; 24: 90-4.

10. Barbalic M, Dupuis J, Dehghan A, et al. Large-scale genomic studies reveal central role of $A B O$ in $s P$ selectin and sICAM-1 levels. Hum Mol Genet 2010; 19: 1863-72.

11. Kiechl S, Paré G, Barbalic M, et al. Association of variation at the ABO locus with circulating levels of soluble intercellular adhesion molecule-1, soluble P-selectin, and soluble E-selectin: a meta-analysis. Circ Cardiovasc Genet 2011; 4: 681-6.

12. Terol MJ, Tormo M, Martinez-Climent JA, et al. Soluble intercellular adhesion molecule-1 (s-ICAM-1/s-CD54) in diffuse large B-cell lymphoma: association with clinical characteristics and outcome. Ann Oncol. 2003 Mar;14 (3): 467-74. doi: 10.1093/annonc/mdg057.

13. Lust JA, Lacy MQ, Zeldenrust SR, Witzig TE, Moon-Tasson LL, Dinarello CA, Donovan KA. Reduction in Creactive protein indicates successful targeting of the IL-1/IL-6 axis resulting in improved survival in early stage multiple myeloma. 2016 Jun;91(6):571-4. doi: 10.1002/ajh.24352.

14. Azab AK, Quang P, Azab F, Pitsillides C, Thompson B, Chonghaile T, et al. P-selectin glycoprotein ligand regulates the interaction of multiple myeloma cells with the bone marrow microenvironment. Blood. 2012 Feb 9; 119 (6): 1468-78. doi: 10.1182/blood-2011-07-368050.

15. Rajkumar SV, Dimopoulos MA, Palumbo A, et al. International Myeloma Working Group updated criteria for the diagnosis of multiple myeloma. Lancet Oncol. 2014; 15: e538-e548.

16. International Agency for Research on Cancer. IARC Monographs on the Evaluation of Carcinogenic Risks to Humans. International Agency for Research on Cancer; Lyon, France: 2014. 
17. Colao A, Muscogiuri G, Piscitelli P. Environment and Health: Not Only Cancer. Int J Environ Res Public Health. 2016 Jul 19;13(7):724. doi: 10.3390/ijerph13070724.

18. Rooks, M.G. \& Garrett W.S. 2016. Gut microbiota, metabolites and host immunity. Nat. Rev. Immunol. 16: 341-352.

19. Arend $P$. Position of human blood group $O(H)$ and phenotype-determining enzymes in growth and infectious disease. Ann N Y Acad Sci. 2018 Aug;1425(1):5-18. doi: 10.1111/nyas.13694.

20. Amundadottir L., Kraft P., Stolzenberg-Solomon R.Z., Fuchs C.S., et al. Genome-wide association study identifies variants in the ABO locus associated with susceptibility to pancreatic cancer. Nature genetics. 2009 41 (9): 986-90.

21. Wang Z, Liu L, Ji J, et al. ABO Blood Group System and Gastric Cancer: A Case-Control Study and MetaAnalysis. Int J Mol Sci. 2012 Oct 17; 13 (10): 13308-21. doi: 10.3390/ijms131013308.

22. Tavasolian F, Abdollahi E, Vakili M, Amini A. Relationship between ABO blood group and Acute Lymphoblastic Leukemia. Iran J Ped Hematol Oncol. 2014; 4 (1): 1-4.

23. Nagy $P$, Jako J, Kiss A, Tamas E, Telek B, Rak K. Sex-linked difference in blood-group distribution among patients suffering from acute leukaemias. $\mathrm{Br} \mathrm{J}$ Haematol. $1981 \mathrm{Jul} ; 48$ (3): 507-8. doi: 10.1111/j.13652141.1981.tb02743.x.

24. Mustacchi P, Shonfeld EM, Lucia S. Survival in Acute Leukemia: The Influence of Blood Groups, Sex, and Age at Onset. Annals of internal medicine. 1960; 52 (5): 1099-107.

25. Steinberg AG, Steinfeld JL. The genetics of acute leukemia in children. Cancer. 1960; 13 (5): $985-99$.

26. Göçer M, Kurtoğlu E. Effect of the ABO blood groups on the development, clinical features and survival of multiple myeloma. Memo. 2020 Dec 23; 1-6. doi: 10.1007/s12254-020-00669-y.

27. Martins LC, de Oliveira Corvelo TC, Oti HT, et al.: ABH and Lewis antigen distributions in blood, saliva and gastric mucosa and $\mathrm{H}$ pylori infection in gastric ulcer patients. World J Gastroenterol 2006; 12:1120-1124.

28. Faruque AS, Mahalanabis D, Hoque SS, et al.: The relationship between ABO blood groups and susceptibility to diarrhea due to Vibrio cholerae 0139. Clin Infect Dis 1994; 18:827-828.

29. Onsten TGH, Callegari-Jacques SM, Goldani LZ. The higher frequency of blood group b in a Brazilian population with HIV Infection. Open AIDS J 2013; 7: 47-50.

30. Perrotta C, Staines A, Cocco P. Multiple myeloma and farming. A systematic review of 30 years of research. Where next? J Occup Med Toxicol. 2008 Nov 17; 3: 27. doi: 10.1186/1745-6673-3-27.

31. Dobrovic A, O'Keefe D, Sage RE, Batchelder E. Imprinting and loss of ABO antigens in leukemia. Blood. 1993; 82 (5): 1684-1685.

32. Waleed MS, Sadiq W. Multiple Myeloma and Change of ABO Blood Group Type: A Case Report. Cureus. 2020 Sep; 12 (9): e10654.

33. van der Hart M, van der Veer M, van Loghem JJ. Change of blood group B in a case of leukemia. Vox Sang. 1962; 7: 449-453.

34. Crookston MC. Anomalous ABO, H, li phenotypes in disease. In: Garratty G, editor. Blood Group Antigens and Disease. Arlington, VA: American Association of Blood Banks; 1983. pp. 67-84.

35. Reid ME, Bird GW. Associations between human red cell blood group antigens and disease. Transfus Med Rev. 1990;4(1):47-55.

36. Kuhns WJ, Oliver RT, Watkins WM, Greenwell P. Leukemia-induced alterations of serum glycosyltransferase enzymes. Cancer Res. 1980; 40 (2): 268-275.

37. Jenkins PV, O'Donnell JS. ABO blood group determines plasma von Willebrand factor levels: a biologic function after all? Transfusion 2006; 46: 1836-44.

38. Pare G, Chasman DI, Kellogg M, et al. Novel association of ABO histo-blood group antigen with soluble ICAM-1: results of a genome-wide association study of 6,578 women. PLoS Genet 2008; 4: e1000118.

39. Franchini M, Frattini F, Crestani S, et al. Von Willebrand factor and cancer: a renewed interest. Thromb Res 2013; 131: 290-2.

40. Kobayashi H, Boelte KC, Lin PC. Endothelial cell adhesion molecules and cancer progression. Curr Med Chem 2007; $14: 377-86$

41. Klausz K, Cieker M, Kellner C, et. al. Fc-engineering significantly improves the recruitment of immune effector cells by anti-ICAM-1 antibody MSH-TP15 for myeloma therapy. Haematologica. 2020 Jun 4. doi: 10.3324/haematol.2020.251371.

42. Sokol J, Hrncar M, Nehaj F, Stasko J. Plasma Levels of Vascular Endothelial Growth Factor and Selected Hemostatic Parameters in Association With Treatment Response in Multiple Myeloma. Clin Appl Thromb Hemost. Jan-Dec 2019; 25:1076029618823280. doi: 10.1177/1076029618823280. 